\title{
Phenotypes, Genotypes and Allele Frequencies of B-lactoglobulin in Egyptian Cattle and Buffalo
}

\author{
Eman Moawed Gouda (Corresponding author) \\ Biochemistry Department, Faculty of Veterinary Medicine, Cairo University \\ PO box 12211, Giza, Egypt \\ Tel: 20-1-2701-0828 E-mail: emanmgouda@hotmail.com \\ Mona Khamees Galal \\ Biochemistry Department, Faculty of Veterinary Medicine, Cairo University \\ PO box 12211, Giza, Egypt \\ Tel: 20-1-8502-0123 E-mail: monakham@yahoo.com \\ Mohsen Ahmed Wasfy \\ Biochemistry Department, Faculty of Veterinary Medicine, Cairo University, \\ PO box 12211, Giza, Egypt \\ Tel: 20-1-0102-2488Ｅ-mail: mwasfy@cu.edu.eg \\ Samy Ahmed Abdelaziz \\ Biochemistry Department, Faculty of Veterinary Medicine, Cairo University, \\ PO box 12211, Giza, Egypt
}

Tel: 20-1-0673-6611Ｅ-mail: samyabziz@hotmail.com

Received: August 9, 2011 Accepted: August 29, 2011 Published: December 1, 2011

doi:10.5539/jas.v3n4p203

URL: http://dx.doi.org/10.5539/jas.v3n4p203

\begin{abstract}
$\beta$-lactoglobulin (B-LG) is the major whey protein and its polymorphic gene affects economical traits in cattle breeds. The present study aims to identify the phenotype, genotype and allelic frequency of B-LG gene among local cattle breeds and Buffalo in Egypt, as the phenotyping and genotyping of that gene have not been extensively studied yet in these breeds. Milk samples from Holestien, Baladi cattle and buffalo were assayed for phenotyping of B-LG as well as well as some milk protein traits. Genotyping of B-LG was performed by PCR-RFLP using Hae III endonuclease digestion of a 262 bp PCR products of exon IV and intron IV. The most frequent phenotype in Holestien cattle, Baladi cattle and Buffalo was the BB variant. AA, AB and BB genotypes were existed in Holestien cattle, meanwhile AB, BB and BC genotypes were present in Baladi cattle and Buffalo breeds in Egypt with the predominance of $\mathrm{BB}$ genotype in the three breeds. The Holestien cattle populations were in Hardy-Weinberg equilibrium while the Baladi cattle and Buffalo were rejected. The allelic frequency of A, B and $\mathrm{C}$ alleles were in the order of $0.205,0.795$ and 0.000 for Holestein cattle, $0.109,0.869$ and 0.022 for Baladi cattle and $0.055,0.917$ and 0.028 for Buffalo. The existence of rare BC genotype and the inbred nature were the most interesting result in the Baladi cattle and Buffalo. These results could be included into marker assisted selection programs to improve response to selection in these local breeds.
\end{abstract}

Keywords: Beta lactoglobulin, Phenotype, Genotype, Cattle and buffalo

\section{Introduction}

Prediction of the future performance of farm animals is the most rational point in animal breeding and animals of superior traits and phenotype should be selected to hasten genetic improvement. The use of polymorphic genes as genetic molecular markers is a promising surrogate to the current methods of selection once these genes are proven 
to be associated with traits of interest in animals. Selection effectiveness depends on allelic frequencies in the breeds and on the effect of these polymorphisms on selected traits (e.g. dairy traits and industrial properties of milk). Therefore they can be used as a suitable supplement to conventional breeding procedures (Přibyl, 1995). As one of the important genes that may affect economically important traits in cattle, $\beta$-lactoglobulin (B-LG) locus has been studied (Tsiaras et al., 2005). The B-LG gene is situated on bovine chromosome 11, encode for a single chain polypeptide of $18 \mathrm{kDa}$ comprising of 162 amino acid residues. The complete amino acid sequence of B-LG has been reported and genetic variation in amino acids sequence has been identified (Hill et al., 1996; Rachagani et al., 2006). Polymorphism of this gene was discovered in 1955 (Aschaffenburg \& Drewry, 1955) and a total of 15 alleles are known, five of these variants; A, B, C, D, and E are well identified (Li, 1997; Elmaci et al., 2006; Matejicek et al., 2007; Meza-Nieto et al., 2007). Common alleles are A, B, C, D, and E with alleles A and B being the most frequent. These two protein variants have small chemical differences between them, where two amino acids, aspartate- 64 and valine-118 in variant A were substituted by glycine and alanine respectively in the B variant (Rachagani et al., 2006).

Many studies were performed to investigate the effect of B-LG genotypes on milk production traits, milk composition and quality. They found that, the AA genotype of $\beta$-LG had a favourable effect on protein yield, and the association of significantly higher fat content, protein, casein, true protein, and total solids with BB variant had been reported (Matejicek et al., 2007; Meza-Nieto et al., 2007).

Phenotyping and genotyping of B-LG gene can be carried out by using alkaline and acidic polyacrylamide gel electrophoresis and PCR-based markers, especially PCR-RFLP, for all individuals in a given population under selection, regardless of sex, age or physiological stage. As a result, it is now possible to include information on milk protein genotypes into marker assisted selection programs and consequently improve response to selection (Karimi et al., 2009 a).

The Egyptian Baladi breed of cattle together with the Egyptian buffalo represents native and low productive dairy animals that are mainly bred in Egypt. Resistance to diseases, adaptation to local environmental condition and their role in the economy of rural families are important reasons for consideration of breeding and genetic improvement of these animals. However, there is little precise knowledge of the distribution of genetic markers for $\beta$ -lactoglobulin among Egyptian dairy cattle and buffalo. The current study is carried out aiming to identify the phenotype frequency and its effects on milk protein variants as well as the genotype and allelic frequency of the B -LG gene in the native breeds of Baladi cattle and buffalo compared to Holestien cattle in Egypt.

\section{Methods}

\subsection{Sampling}

Blood and milk samples were collected from dairy cows and buffalo from the farms of Faculty of Veterinary medicine, Faculty of Agriculture, Cairo University and private farms in Egypt (Holstein cattle, Baladi cattle and buffalo) at the period from December to February, 2009. Animals were unrelated individuals following the recommendations spread by ISAG/FAO advisory group on animal genetic diversity (FAO, 1998).

\subsection{Milk proteins and BLG phenotyping}

The individual milk samples were collected immediately after milking for total proteins and total whey proteins determination. The Casein content was derived from the difference between total proteins and whey proteins. Total protein was assayed according to Kamizake et al. (2007), while whey proteins were assayed using the calorimetric technique with commassie brilliant blue according Bradford (1976). The whey fraction was separated from milk samples (de jongh et al., 2001) and fractionated on $15 \%$ polyacrylamide gel at $\mathrm{pH} 8.3$ (Laemmli, 1970).

\subsection{Genomic DNA isolation}

Blood samples were collected in vacutainers containing sodium EDTA as an anticoagulant. Genomic DNA was isolated from each blood sample using standard salt out method according to Helms (2002). Quality and quantity of DNA were checked electrophoretically on $1 \%$ agarose and spectrophotometrically at 260 and $280 \mathrm{~nm}$ respectively.

\subsection{B-LG genotyping}

The sequences of the primers were as follows: Sense primer 5' GTCCTTGTGCTGGACACCGACTACA3'(forward) and antisense primer CAGGACACCGGCTCCTGGTATATGA3'(reverse) and used to amplify $262 \mathrm{bp}$ fragment of B-LG gene (Meignanalakshmi et al., 2001). PCR was carried out in a total volume of $50 \mu$ l containing: 5X PCR Taq Master/ 
high yield (JenaBioscience, Germany); 1X BSA; 25 pmol of each primer and $200 \mathrm{ng}$ of genomic DNA. Amplification was carried out in an automated thermal cycler for 35 cycles of denaturation for $40 \mathrm{sec}$. at $95^{\circ} \mathrm{C}$, annealing for $40 \mathrm{sec}$. at $64{ }^{\circ} \mathrm{C}$, and extension for $40 \mathrm{sec}$. at $72{ }^{\circ} \mathrm{C}$, with initial denaturation at $95^{\circ} \mathrm{C}$ for $3 \mathrm{~min}$ and final extension for $10 \mathrm{~min}$ at $72{ }^{\circ} \mathrm{C}$. Amplification was verified by electrophoresis on $2 \%(\mathrm{w} / \mathrm{v})$ agarose gel.

\subsection{Restriction fragment length polymorphism (RFLP)}

The amplicons were digested in total reaction mixture of $20 \mu \mathrm{l}$ containing $17 \mu \mathrm{l}$ PCR, $5 \mathrm{U}$ of the restriction enzyme Hae III (JenaBioscience, Germany) and $2.5 \mu \mathrm{l}$ of restriction endonuclease buffer with BSA, the reaction were incubated at $37^{\circ} \mathrm{C}$ for at least about 3 hours. The restriction digested fragments were separated on $12 \%$ non-denaturing PAGE and the gels were stained by etheduim bromide $(1 \mathrm{mg} / \mathrm{ml})$.

\subsection{Statistical analysis}

Direct counting was used to estimate phenotype and allele frequencies of $\beta$ - lactoglobulin genetic variants. The chi-square test $\left(\chi_{2}\right)$ was used to check whether the populations were in Hardy-Weinberg equilibrium. Allele frequencies and mean expected heterozygosities per locus and population were calculated using Arlequin ver. 3.11 package program (Excoffier \& Heckel, 2006).

\section{Results}

Whey proteins of the dairy breeds (Holestien cattle, Baladi cattle and Buffalo) were separated on $15 \%$ native PAGE at $\mathrm{pH}$ 8.3, and revealed the existence of 3 phenotypes (AA, AB and BB) of B-LG protein as shown in Fig.1.

The distribution of B-LG phenotypes demonstrated that $\mathrm{BB}$ variant was the most frequent one among the three phenotypes (AA, AB and $\mathrm{BB}$ ) which reported in the Holestien cattle. While in both Baladi cattle and Buffalo, only two phenotypes were existed (AB and $\mathrm{BB}$ ) with the predominance of $\mathrm{BB}$ phenotype (Table, 1).

Notably, a positive effect on the concentration of total protein and casein number as well as casein percent was attributed to BB phenotype in Buffalo only, while, B-Lg phenotypes had no effect on milk proteins traits in both Holestien and Baladi cattle (table, 2).

Characterization of B-LG gene and allele frequency were analyzed by PCR-RFLP technique. The restriction digestion analysis of the $262 \mathrm{bp}$ PCR products of B-LG in the studied dairy breeds indicated the presence of 4 types of restriction pattern; AA genotype with 2 fragments of 154 and 109 bp, BB genotype with 3 fragments of 109, 79, $74 \mathrm{bp}, \mathrm{AB}$ genotype with 4 fragments of 154, 109, 79 and 74bp and the last pattern, a rare genotype, BC that had 3 fragment 154, 79 and 74bp (Fig.2).

The results of PCR-RFLP demonstrated the presence of AA, AB and BB genotypes in Holestien cattle, and AB, $\mathrm{BB}$ and $\mathrm{BC}$ genotypes in the Egyptian Baladi cattle and Buffalo with the predominance of the BB genotype among the three breeds. The frequency of $\mathrm{A}, \mathrm{B}$ and $\mathrm{C}$ alleles were in the order of $0.205,0.795$ and 0.000 for Holestein cattle, $0.109,0.869$ and 0.022 for Baladi cattle and 0.055, 0.917 and 0.028 for Buffalo. The Deviation from Hardy-Weinberg equilibrium was detected in both Baladi cattle and Buffalo, while Holestien cattle are in Hardy-Weinberg equilibrium (Table, 3 ).

\section{Discussion}

B-Lactoglobulin is the major whey protein in ruminant milk. Polymorphism of B-lactoglobulin has a high interest since their variants are associated with milk production performance, its quality and processing (Matejicek et al., 2007; Meza-Nieto et al., 2007). The most predominant phenotype of B-LG in the present study was the BB with absence of AA phenotype in both Baladi cattle and Buffalo (table, 1). The lack of AA phenotype in Baladi cattle and Buffalo in the present study is in line with Karimi et al (2009b) who reported the absence of AA variant in Najdi cattle and in Iranian buffalo. Besides, BB phenotype is the most predominant phenotype in Holestien cattle in the current study (Table, 1). Previous studies demonstrated that, the heterozyote AB genotypes were found to be more frequent in Holestien cows (Hill et al., 1996; Oner \& Elamci, 2006) and in Tharparkar cattle (Rachagani et al., 2006) . Notably, B allele of B-LG gene was found to be the most frequent variant among dairy breeds worldwide; in Indian Zebu cattle (Singh and Bhat, 1980), in Lihuanian Red breed (Miceikiene et al., 2006), In Sahiwal cattle (Rachagani et al, 2006), Holestien Friesian cattle (Ilie et al., 2007), Holestien and Girolando (Botaro et al., 2008), Iranian Najdi cattle (Karimi et al., 2009a) and Romanian Simmental cattle (Ilie et al., 2010). On the other hand, Curil et al (2005) reported higher frequencies of allele A in their study.

A well-established notion of Bobe et al (1999) that, $\beta$-LG genotypes influenced the genotypic and phenotypic variability of milk protein composition, without significant effect on the concentration of milk proteins. In the context, a marked positive effect was attributed to B-LG BB phenotype of buffalo on the concentration of total proteins, total casein and casein number compared to the other phenotypes (table 2). 
In line, Uhrin et al (1995) demonstrated a positive association between of the BB genotype of B-LG and higher fat and casein content in Holstein Friesian, Black Pied Lowland, Simmental and Peinzgau breeds. In the same line, Michalcová \& Krupová (2007) on their study on Slovak Pied breed of dairy cattle reported a positive significant effect of $\beta-\operatorname{Lg} B B$ on casein content and casein number. The milk produced by BB genotype cows yielded significantly more cheese than that produced by AA-genotype cows (Patel et al., 2007). Whereas, the results of Sabour et al (1996) and Tsiaras et al (2005) pointed to the association between B-LG genotype AB and high milk and protein production.

There is a comparably strong rationale for a positive effect of $\beta-\operatorname{Lg} B$ allele on the protein content (Miceikiene et al., 2006) and on casein content (Celik, 2003) rendering milk from cattle breeds carrying this allele more desirable for cheese making.

On the other hand, Botaro et al (2008) observed no association between milk composition and B-LG genetic polymorphism.

In the present study, we demonstrated that the frequency of BB genotype is the highest among Holestien cattle, Baladi cattle and Buffalo breeds in Egypt (Table, 3). These data are in the context with Patel et al (2007) who reported the highest frequency of BB genotype in Indian cattle. Likewise, BB genotype was the most frequent for Holstien and Girolando breeds (Botaro et al., 2008) and also among Lithuanian Red cattle breed (Miceikiene et al., 2006).

A surprising finding of our study is the presence of a rare genotype which is $\mathrm{BC}$ variant and lack of AA genotype among both Baladi cattle and Buffalo in Egypt as shown in table 3.

$\beta-\mathrm{LG}$ allele $\mathrm{C}$ is not a common allele, it was found in Australian Jersey (Bell, 1962), in German Jersey (Erhardt, 1993), in Cuban zebu (Perez-Beato, 1979) and in Pamir yak (Lozovaya, 1973). The BC genotype was found at a low frequency in Lithuanian Red breed (Miceikienè et al., 2006). Patel et al, (2007) reported both BC and AA variants in Indian buffalo.

The studies that carried out on Iranian buffalo and Najdi cattle reported the absence of AA genotype (Karimi et al., 2009 a, b), is in line with our result in both Baladi cattle and Buffalo. On the other hand, Meignanalakshmi \& Mahalinga Nainar (2009) reported that, no polymorphism was present in B-LG gene locus in Murrah buffalo.

As a consequence of rarity of literature on B-lactoglobulin in buffalo, a sort of difficulty has been arisen to compare our results on Egyptain buffalo with others.

It is obvious from our results that B allele is the most frequent allele in the three studied breeds (table, 3). Likewise, the frequency of A allele was found to be lower than that of the B allele in both Iranian Najdi cattle and buffalo, (Karimi et al., 2009b), in Bos taurus (Kucerova et al., 2006; Matejicek et al., 2007), Bos indicus (Kemenes et al., 1999; Patel et al., 2007) in Gyr, Nelore, Sindi (Del lama \& Zago 1996) and in Sahiwal and Tharparkar cattle (Rachagani et al., 2006). Also, Celik (2003) and Oner \& Elmaci (2006) reported higher frequencies for the B allele for Holstein cows.

Therefore, the required crossbreeding ratio with superior individuals of local and foreign cattle breeds carry the favorite genotypes of this gene will lead to increasing the expression of this gene in the local Egyptian cattle and Buffalo breeds without affecting the acclimatization traits of these breeds to the environmental conditions in Egypt.

\section{References}

Aschaffenburg, R. \& Drewry, J. (1955). Occurrence of different b - lactoglobulin in cow's milk. Nature, 176, 218-210. http://dx.doi.org/doi.org/10.1038/176218b0

Bell, K. (1962). One-dimensional starch-gel electrophoresis of bovine skim-milk. Nature, 195, 705-706. http://dx.doi.org/10.1038/195705a0

Bobe, G., Beitz, D. C., Freeman, A.E. \& Lindberg, G.L. (1999). Effect of milk protein genotypes on milk protein composition and its genetic parameter estimates. Journal of Dairy Science, 82: 2797-2804. http://dx.doi.org/10.1051/dst/2008039

Botaro, B., Lima, Y., Aquino, A., Fernandes,R., Garcia, J. \& Santos, M. (2008). Effect of beta-lactoglobulin polymorphism and seasonality on bovine milk composition. Journal of Dairy Research, 75, 176-181. http://dx.doi.org/10.1017/S0022029908003269

Bradford, M .M. (1976). A rapid sensitive method for the quantitation of microgram quantities of protein utilizing the principle of protein dye binding. Analytical Biochemistry, 72, 248. 
http://dx.doi.org/10.1016/0003-2697(76)90527-3

Celik, S. (2003). b-lactoglobulin genetic variants in Brown Swiss breed and its association with compositional properties and rennet clotting time of milk. International Dairy Journal, 13, 727-731. http://dx.doi.org/10.1016/S0958-6946(03)00093-1

de JONGH, H. H., GRÖNEVELD, T. \& DE GROOT, J. (2001). Mild isolation procedure discloses new protein structural properties of beta-lactoglobulin. Journal of Dairy Science, 84(3), 562-571. http://dx.doi.org/10.3168/jds.S0022-0302(01)74508-0

Del Lama, S. N. \& Zago, M. A. (1996). Identification for the kappa-caesin and beta-actoglobulin genotypes in Brazilian Bos indicus and Bubalis bubalis population. Brazilian Journal of Genetics, 19, 73-77.

Elmaci, C., Oner, Y., \& Balcioglu, M. S. (2006). Genetic Polymorphism of $\beta$-Lactoglobulin Gene in Native Turkish Sheep Breeds. Biochemical Genetics, 44(7/8), 376-381. http://dx.doi.org/10.3923/ajava.2009.130.133

Erhardt, G. (1993). Allele frequencies of milk proteins in Germancattle breeds and demonstration of $\alpha$ s-casein variants by isoelectric focusing. "Archiv für Tierzucht, Dummerstorf", 36, 145-152 http://dx.doi.org/10.1111/j.1365-2052.1993.tb00922.x.

Excoffier, L. \& Heckel, G. (2006). Computer programs for population genetics data analysis: a survival guide. Nature Reviews Genetics, 7(10), 745-758. http://dx.doi.org/10.1038/nrg1904

FAO. (1998). Secondary Guidelines for Development of National Farm Animal Genetic Resources Management Plans. Measurement of Domestic Animal Diversity (MoDAD): Original Working Group Report. Rome. pp. 55. [Online] Available: http://www.fao.org/ag/againfo/resources/en/pubs_gen.html

Helms, C. (2002). Salting out Procedure for Human DNA extraction. In: The Donis-Keller Lab - Lab Manual Homepage. [Online] Available : http://hdklab.wustl.edu/lab_manual/dna/dna2.html

Hill, J. P., Boland, M. J., Creamer, L. K., Anema, S. G., Otter, D. E., Paterson, G. R., Lowe, R., Motion, R. L., \& Thresher, W. C. (1996). Effect of the bovine $\beta$-lactoglobulin phenotype on the properties of $\beta$-lactoglobulin, milk composition, and dairy products. In: Macromolecular Interactions in Food Technology (Eds Parris, N., Kato, A., Creamer, L. K. and Pearce, J.). ACS symposium series. 650, 281-294. http://pubs.acs.org/doi/abs/10.1021/bk-1996-0650.ch022

Ilie, D., Sălăjeanu, A., Magdin, A., Stanca, C., Vintilă, C., Vintilă, I.\& Gócza, E.(2007).Genetic polymorphism at the k-casein locus in a dairy herd of Romanian Spotted and Brown of Maramures breeds. Lucrări ştiințifice Zootehnie şi Biotehnologii, Timişoara, 40 (1), 101-105.

Ilie, D., Sălăjeanu, A., Magdin, A., Neamț, R. \& Vintila, I. (2010). Early Determination of Animals with Favorable Genes in Milk Production for Profitable Private Farms. Animal Science and Biotechnologies, 43 (1), 279-282.

Kamizake, N. K. K., Gonçalves, M. M., Zaia, C.T. B. V. \& Zaia, D. A. M. (2003). Determination of total proteins in cow milk powder samples: a comparative study between the Kjeldahl method and spectrophotometric methods. Journal of Food composition and analysis,. 16 (4), 507-516. http://dx.doi.org/10.1016/S0889-1575(03)00004-8

Karimi, K., Beigi Nasiri, M. T., Ashayerizadeh, A. \& Fayyazi, J. (2009a). Polymorphism of the $\beta$-lactoglobulin gene and its association with milk production traits in Iranian Najdi cattle. Iranian Journal of Biotechnology, 7(2), $82-85$.

Karimi, K., Beigi Nasiri, M. T., Fayyazi, J., Mirzadeh, K. H. \& Roushanfekr, H. (2009b). Allele and genotype frequencies of $\beta$-lactoglobulin gene in Iranian Najdi cattle and buffalo populations using PCR-RFLP. African Journal of Biotechnology, 8 (15), 3654-3657.

Kemenes, P.A., Regitano, L.C.A., Rosa, A.J., Packer, I.U., Razook, A.G., Figueiredo, L.A. \& Coutinho L (1999). Kappa casein, beta-lactoglobulin and growth hormone allele frequencies and genetic distances in Nelore, Gyr, Guzera, Caraco, Charolois, Canchim and Santa Gertrudis cattle. Genetics and Molecular Biology, 22, 539-541. http://dx.doi.org/10.1590/S1415-47571999000400012

Kucerova, J., Matejicek, A., Jandurova, O.M., Sqrensen, P., Kott, T. \& Frelich, J. (2006). Milk protein gene CSN1S1, CSN2, CSN3, LGB and their relation to genetic value of milk production parameters in Czech Fleckvieh. Czech Journal of Animal Science, 51, 241-247.

Laemmli, U. K. (1970). Cleavage of structural proteins during the assembly of the head bacteriophage T4. Nature, 227,680-685. http://dx.doi.org/10.1038/227680a0 
Li, J. (1997). Effects of Genetic Variants of K-Casein and P-Lactoglobulin on Heat Denaturation of Milk Proteins and Formation of Protein Complex. M.Sc. Thesis, McGill University, Faculty of Graduate Studies and Research. Department of Animal Science. Montreal, Canada.

Lozovaya, G.S. (1973). Genetic variation in haemoglobin, transferrin and $\beta$-lactoglobulin types in yaks from the Pamirs. Tsitologiya i Genetika, 7(2), 158-160.

Matejicek, A., Matejickova, J., Nemcova, E. \& Frelich, J. (2007). Joint effect of CSN3 and LGB genotypes and their relation to breeding values of milk production parameters in Czech Fleckvieh. Czech Journal of Animal Science, 52, 83-87.

Meignanalakshmi, A., Mahalinga Nainar, A. \& Nachimuthu, K. (2001). Identification of genetic polymorphism of beta- lactoglobulin gene locus in Red Sindhi cows by PCR-RFLP Analysis. International Journal of Animal Science, 16, 223-226.

Meignanalakshmi, S. \& Mahalinga Nainar, A. (2009). PCR-RFLP analysis of Beta-lactoglobulin gene in Murrah buffaloes. Tamilnadu Journal of Veterinary \& Animal Sciences, 5 (5), 194-197.

Meza-Nieto, M. A., Vallejo-Cordoba, B., Gonza'Lez-Co' Rdova, A. F. Fe' Lix, L. \& Goycoole, F. M. (2007). Effect of $\beta$-Lactoglobulin A and B Whey Protein Variants on the Rennet-Induced Gelation of Skim Milk Gels in a Model Reconstituted Skim Milk System. Journal of Dairy Science, 90, 582-593. http://dx.doi.org/10.3168/jds.S0022-0302(07)71541-2

Miceikienė, I., Pečiulaitienè, N., Baltrènaitè, L., Skinkytė, R. \& Indriulytè, R. (2006). Association of cattle genetic markers with performance traits. Biologija, 1, 24-29.

Michalcová, A. \& Krupová, Z. (2007). Influence of composite $\kappa$-casein and $\beta$-lactoglobulin genotypes on composition, rennetability and heat stability of milk of cows of Slovak Pied breed. Czech Journal of Animal Science, 52 (9), 292-298.

Oner, Y. \& Elmaci, C. (2006). Milk protein polymorphisms in Holstein cattle. International Journal of Dairy Technology, 59, 180-182. http://dx.doi.org/10.1111/j.1471-0307.2006.00259.x

Patel, K. R., Chauhan, J.B., Krishna, M.S. \& Soni, K.J. (2007). Allelic frequency of kappa-casein and betalactoglobulin in Indian crossbred dairy bulls. Turkish Journal of Animal Science, 31, 399-402.

Patel, R. K., Chauhan, J. B., Singh, K. M. \& Soni, K. J. (2007). Genotype and allele frequencies of א-casein and $\beta$-lactoglobulin in indian river buffalo bulls (bubalus bubalis). Buffalo bulletin, 26 (3). 63-66.

Pérez-Beato, O. (1979). Presencia de la variante C del locus $\beta$-Lg en el cebu de Cuba. Revista de Salud Animal, 1(1), 101-103.

PŘIBYL, J. (1995). A way of using markers for farm animal selection. Czech Journal of Animal Science, 40,375-382.

Rachagani, S., Gupta, I. D., Gupta, N. \& Gupta, S. C. (2006). Genotyping of beta-lactoglobulin gene by PCR-RFLP in Sahiwal and Tharparkar cattle breeds. BMC Genetics, 7, 31-34. doi.org/10.1186/1471-2156-7-31

Sabour, M. P., Lin, C.Y., Lee, A. J. \& Mcallister, A. J. (1996). Association between milk protein genetics variants bulls for milk yield traits. Journal of Dairy Science, 79, 1050-1056. http://dx.doi.org/10.3168/jds.S0022-0302(05)72692-8.

Singh, H. \& Bhat, P.N. (1980). b-lactoglobulin polymorphism in indigenous cattle. Indian Journal of Animal Science, 50, 932-937.

Tsiaras, A. M., Bargouli, G. G., Banos, G. \& Boscos, C. M, (2005). Effect of kappa Casein and beta Lactoglobulin loci on milk production traits and reproductive performance. Journal of Dairy Science, 88, $327-334$. http://dx.doi.org/10.3168/jds.S0022-0302(05)72692-8.

Uhrin, P., Chrenek, P., Vasicek, D., Bauerova, M.\& Bulla, J. (1995). Genotyping of beta-lactoglobulin gene in different breeds of cattle in Slovakia. Animal genetics and breeding, 40(2), 49-52. 
Table 1. The distribution of $\beta-L G$ phenotypes and allele frequencies in Holestien cattle, Baladi cattle and Buffalo in Egypt and Hardy-Weinberg equilibrium

\begin{tabular}{|c|c|c|c|c|c|c|}
\hline \multicolumn{2}{|l|}{ Animal breed } & \multicolumn{3}{|c|}{ Phenotype } & \multicolumn{2}{|c|}{ Allelic frequency } \\
\hline & & AA & $\mathrm{BB}$ & $\mathrm{AB}$ & A & $\mathrm{B}$ \\
\hline \multirow[t]{4}{*}{ Holestien cattle } & Obs. & 8 & 76 & 20 & \multirow{4}{*}{0.173} & \multirow{4}{*}{0.827} \\
\hline & Exp. & 20.32 & 51.3 & 32.38 & & \\
\hline & Genotype frequency & 0.077 & 0.731 & 0.192 & & \\
\hline & $\chi^{2}$ & \multicolumn{3}{|c|}{$24.049 * * *$} & & \\
\hline \multirow[t]{4}{*}{ Baladi cattle } & Obs. & 0 & 40 & 16 & \multirow{4}{*}{0.143} & \multirow{4}{*}{0.857} \\
\hline & Exp. & 0.57 & 41.12 & 13.72 & & \\
\hline & Genotype frequency & 0.00 & 0.714 & 0.286 & & \\
\hline & $\chi^{2}$ & \multicolumn{3}{|c|}{$0.798^{\mathrm{ND}}$} & & \\
\hline \multirow[t]{4}{*}{ Buffalo } & Obs. & 0 & 98 & 22 & \multirow{4}{*}{0.092} & \multirow{4}{*}{0.908} \\
\hline & Exp. & 1.0068 & 99.023 & 19.97 & & \\
\hline & Genotype frequency & 0.00 & 0.817 & 0.183 & & \\
\hline & $\chi^{2}$ & \multicolumn{3}{|c|}{$0.308^{\mathrm{ND}}$} & & \\
\hline
\end{tabular}

$\chi^{2}=$ chi-square value; Obs.: observed frequencies; Exp.: expected frequencies on the basis of Hardy-Weinberg law.

$* * *$ statisticlly significant, the population is in Hardy-Weinberg frequencies is not rejected

Table 2. Effect of $\beta$-LG phenotypes on milk protein traits in Holestien cattle, Baladi cattle and Buffalo

\begin{tabular}{|c|c|c|c|c|c|}
\hline Animal breed & & Total protein $(\mathrm{g} / \mathrm{l})$ & Toal whey $(\mathrm{g} / \mathrm{l})$ & Casein $(g / L)$ & Casein number $\%$ \\
\hline \multirow[t]{3}{*}{ Holestein Cattle } & AA & $34.70 \pm 1.61$ & $4.34 \pm 0.32$ & $30.36 \pm 1.35$ & $87.5 \pm 0.55$ \\
\hline & $\mathrm{AB}$ & $35.46 \pm 0.79$ & $4.30 \pm 0.15$ & $31.09 \pm 0.80$ & $87.47 \pm 0.53$ \\
\hline & BB & $32.43 \pm 1.25$ & $3.86 \pm 0.25$ & $28.58 \pm 1.27$ & $87.93 \pm 0.94$ \\
\hline \multirow[t]{3}{*}{ Baladi cattle } & AA & ---- & --- & -- & -- \\
\hline & $\mathrm{BB}$ & $30.74 \pm 2.22$ & $3.61 \pm 0.11$ & $27.67 \pm 0.78$ & $88.12 \pm 0.36$ \\
\hline & $\mathrm{AB}$ & $33.18 \pm 1.86$ & $4.08 \pm 0.19$ & $23.71 \pm 0.57$ & $85.32 \pm 0.50$ \\
\hline \multirow[t]{3}{*}{ Buffaloe } & AA & --- & -- & -- & -- \\
\hline & $\mathrm{BB}$ & $31.29 \pm 0.79 *$ & $3.50 \pm 0.66^{*}$ & $27.79 \pm 1.57^{*}$ & $88.81 \pm 1.70^{*}$ \\
\hline & $\mathrm{AB}$ & $27.8 \pm 1.45^{*}$ & $4.43 \pm 0.47 *$ & $23.37 \pm 1.39^{*}$ & $84.06 \pm 0.76^{*}$ \\
\hline
\end{tabular}

** statistically significant. 
Table 3. The distribution of $\beta$-LG genotypes and allele frequencies in Holestien cattle, Baladi cattle and Buffalo in Egypt and Hardy-Weinberg equilibrium

\begin{tabular}{|c|c|c|c|c|c|c|c|c|}
\hline \multicolumn{2}{|l|}{ Animal breed } & \multicolumn{4}{|c|}{ Genotype } & \multicolumn{3}{|c|}{ Allelic frequency } \\
\hline & & AA & $\mathrm{BB}$ & $\mathrm{AB}$ & $\mathrm{BC}$ & A & B & $\mathrm{C}$ \\
\hline \multirow[t]{4}{*}{ Holestien cattle } & Obs. & 4 & 30 & 10 & 0 & \multirow{4}{*}{0.205} & \multirow{4}{*}{0.795} & \multirow{4}{*}{0.00} \\
\hline & Exp. & 1.85 & 27.81 & 14.34 & 0 & & & \\
\hline & Genotype frequency & 0.09 & 0.68 & 0.23 & 0.0 & & & \\
\hline & $\chi^{2}$ & \multicolumn{4}{|c|}{$4.01 * * *$} & & & \\
\hline \multirow[t]{4}{*}{ Baladi cattle } & Obs. & 0 & 34 & 10 & 2 & \multirow{4}{*}{0.109} & \multirow{4}{*}{0.869} & \multirow{4}{*}{0.022} \\
\hline & Exp. & 0.556 & 34.74 & 8.714 & 1.996 & & & \\
\hline & Genotype frequency & 0.00 & 0.74 & 0.217 & 0.043 & & & \\
\hline & $\chi^{2}$ & \multicolumn{4}{|c|}{$0.754^{\mathrm{ND}}$} & & & \\
\hline Buffalo & Obs. & 0 & 60 & 8 & 4 & \multirow{4}{*}{0.055} & \multirow{4}{*}{0.917} & \multirow{4}{*}{0.028} \\
\hline & Exp. & 0.218 & 60.49 & 7.259 & 4.033 & & & \\
\hline & Genotype frequency & 0.00 & 0.833 & 0.111 & 0.055 & & & \\
\hline & $\chi^{2}$ & \multicolumn{4}{|c|}{$0.1347^{\mathrm{ND}}$} & & & \\
\hline
\end{tabular}

$\chi^{2}=$ chi-square value; Obs.: observed frequencies; Exp.: expected frequencies on the basis of Hardy-Weinberg law.

*** statisticlly significant, the population is in Hardy-Weinberg frequencies (is not rejected)
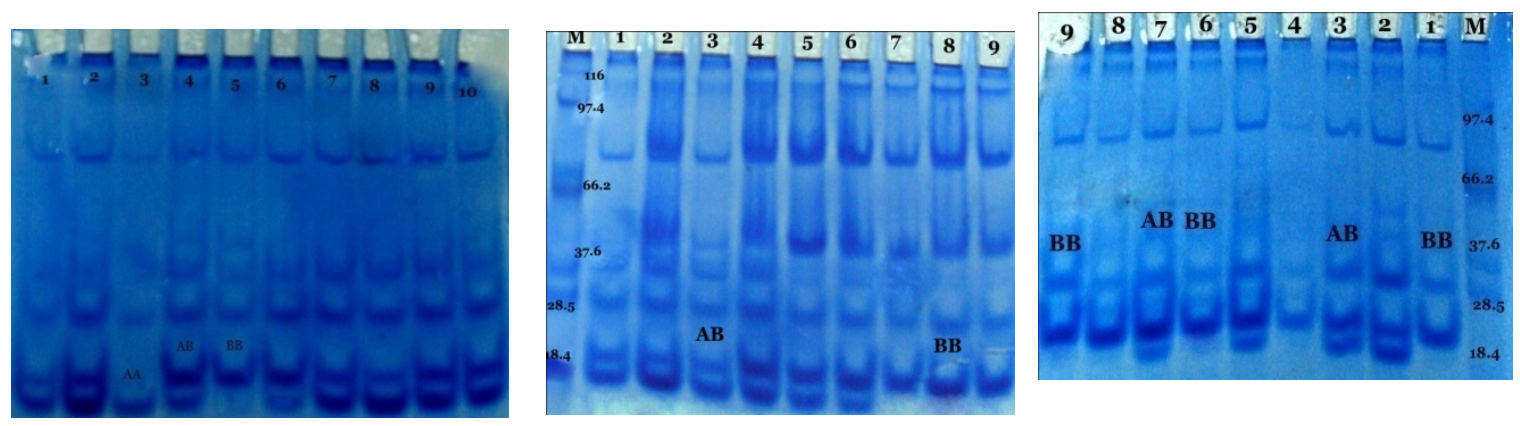

A: whey proteins of Holestein cattle $\quad B$ : whey proteins of Baladi cattle $\quad C$ : whey proteins of Buffalo

Figure 1. Electrophoretic profile of whey proteins from different animal breeds on $15 \% \mathrm{PAGE}$ at $\mathrm{pH} 8.3$

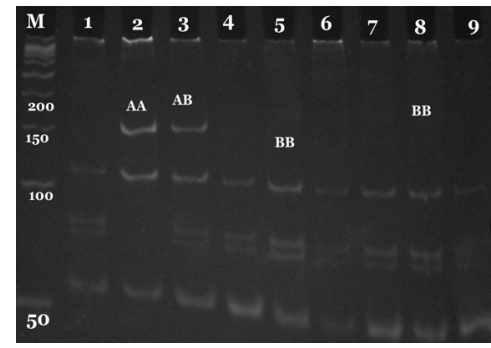

A- PCR-RFLP pattern in Holstein cattle

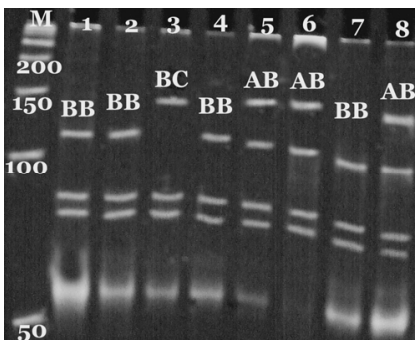

B- PCR-RFLP pattern in

Baladi cattle

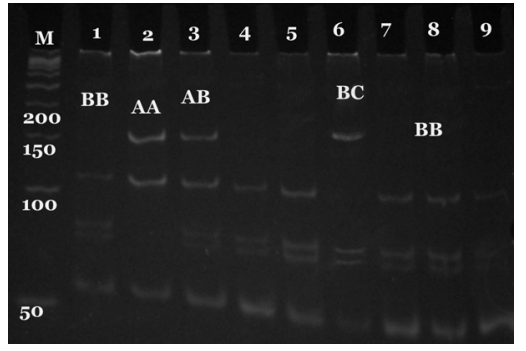

C- PCR-RFLP pattern in buffaloes

Figure 2. Electrophoretic patterns of 262 bp PCR products of $\beta$-lactoglobulin gene digested with Hae III endonuclease on $12 \%$ PAGE. 